\title{
Managerial Perceptions of Privatization: Evidence from a State Department of Transportation
}

\author{
Leisha DeHart-Davis and Gordon Kingsley
}

A RGUMENTS IN favor of privatization pose what are referred to here as Rainey's conundrum (2003). Rainey notes that one of the key rationales offered for privatization is that the public sector is poorly managed. Ironically, however, successful privatization requires outstanding publicsector management. In particular, the move from a centralized command-and-control style bureaucratic structure to contract-based program delivery demands a sophisticated set of managerial skills and structural changes that would challenge the most efficient and effective organization regardless of sector affiliation (Cooper 2003).

The managerial requirements of privatization for midlevel managers - the focus of this article-are particularly significant. With respect to contracting out, managers can be involved in preparing requests for proposals, reviewing submitted proposals, providing input into contracting decisions, crafting contract language, and ushering contracts through internal approval processes (Seidenstat 1999, 240; Rusten 1999, 190). Once contracts have been signed, midlevel managers may be the primary overseers of contractors, providing direction, monitoring contractual tasks, and ensuring compliance with contract terms (Seidenstat 1999, 240). While not a technical step in contracting out, building relationships with contractors is a necessary step toward facilitating effective alternative service delivery (Cooper 2003, 101).

Despite their significant contribution to privatization processes, midlevel managers have largely been ignored in studies of privatization's stakeholders. Rather, more attention has been devoted to the privatization responses of citizens, political leaders, city managers, and state agency directors. Studies examining citizen attitudes toward privatization have argued the importance of public opinion to political support for privatization and the strategic value of such information (Durant and Legge 2002; Thompson and Elling 2000). The attitudes of state legislators toward contracting out have been justified by the importance of legislative support to administrators in designing alternative service-delivery systems (Becker and Mackelprang 1990). Studies of city managers have focused on the relationship between their government reform values and the level of reform activity in their cities (Moon and deLeon 2001), as well as the number of reform recommendations they make to city councils (Kearney, Feldman, and Scavo 2000; Kearney and Scavo 2001). Finally, state-level reinvention efforts have been studied as a function of 
state agency directors' commitment to customer service and organizational leadership (Brudney, Hebert, and Wright 1999).

Taken together, these studies suggest that (1) the attitudes of privatization's stakeholders matter to the success of implementation efforts and (2) understanding the factors driving stakeholder attitudes may yield information that can be strategically used to improve those attitudes. Public managers, one sort of stakeholder, may perceive privatization initiatives as detrimental to themselves or the agencies for which they work. Accordingly, these managers may fail to adjust to privatization, potentially leading to lower morale and higher turnover (Kettl 1993, 59), a decline in public service ethics (Haque 1996), or sabotage of privatization processes (President's Commission on Privatization 1988, 136). Alternatively, positive perceptions of privatization may facilitate more successful privatization efforts (Savas 2000). These assertions assume a bottom-up perspective on program implementation, one that assigns significant power to the employees in charge of executing public initiatives (Lipsky 1980; Maynard-Moody and Musheno 2003).

With these rationales in mind, this study examines individual characteristics associated with managerial perceptions of privatization. The managerial characteristics of interest include professional identity, beliefs about privatization's impacts on professional self-interest, and relationships between public managers and contractors. Borrowing from theories of bureaucratic behavior, public choice, and regulatory capture, professional identity is expected to be associated with more negative perceptions toward privatization, whereas stronger relationships between managers and contractors and beliefs about privatization's professional benefits should be associated with more favorable perceptions. In addition to testing the utility of the bureaucratic behavior theories in which these hypotheses are grounded, examining the relationship between these attributes and managerial perceptions of privatization provides practical knowledge of the factors that can be manipulated to improve managerial receptivity to privatization.

Mail survey results from a sample of managers within the Georgia Department of Transportation provide the study data. Respondents are engineers and other managers in the agency whose work has been subject to significant contract competition. The agency's primary privatization mechanism is contracting out, the most common form of privatization, which involves hiring private-sector firms to provide services (GAO 1997). The pace of privatization has been quite rapid: in 1997, the agency contracted out 10 percent of the engineering design work. Currently, 50 percent of this work is performed through contracts.

\section{Literature Review and Hypotheses}

To begin with, a manager's professional identity may influence perceptions of privatization. While definitions of professionalism vary widely (Schott 1976), they tend to focus on specialized education, autonomy, clear boundaries within which professionals have exclusive prerogative to operate, and differentiation of professional fields from nonprofessionalized work (Mosher 1982; Goode 1969). Professional identity is defined here as an individual's psychological orientation as a professional, an assertion consistent with the contention that professionalism is partly a matter of self-concept (Edwards, Nalbandian, and Wedel 1981; Hall 1968). Privatization may contradict professional identity by requiring professionals to interact interdependently with contractors, blurring the boundaries within which agency professionals operate, and displacing professional tasks with managerial ones. In support of the latter point, privatization sometimes shifts public employees' daily tasks from work for which they have been trained to contract monitoring and compliance, for which they have not been trained (Kettl 1993). Bureaucratic tasks generally have been shown to alienate 
professionals more so than nonprofessionals, presumably by limiting participation in core organizational tasks and curtailing professional autonomy (Greene 1978; Miller 1967). Accordingly, it is expected that

Hypothesis 1: Agency managers with stronger professional identity will perceive privatization more negatively than those with weaker professional identities.

Singer (2003) notes a similar phenomenon when militaries contract with private firms for a variety of services (including mercenary ones). The U.S. military in particular engenders a very specific form of professional identity and culture that may be violated by interactions with private-sector contractors. These tensions have also been noted between the U.S. military and American contractors currently serving in Iraq (National Public Radio 2005).

A contrasting point of view comes from the public choice perspective, which suggests that managers perceive privatization favorably because of its positive impacts on their professional self-interest. This approach assumes that bureaucrats "evaluate and support, undermine or nullify reform proposals on the basis of what new rules imply for their interest" (Wade 1979, 350). The traditional public choice approach argues that bureaucratic selfinterest is reflected by larger budgets, which are assumed to secure political survival, higher salaries, perquisites, and power (Breton 1974; Buchanan and Tullock 1962; Buchanan 1977; Niskanen 1971). Thus, public servants might be expected to resist privatization because of its potential to slow expansion of the public sector, limit personal influence and the size of public budgets, lower public spending, and expand the role of market forces (Dunleavy 1992; Wise and Szucs 1996).

Other public choice theorists have raised the possibility that budget minimization may advance bureaucratic self-interest by enabling professional advancement (Wade 1979; Breton and Wintrobe 1975; Sigelman 1986). Given the political popularity of privatization ini- tiatives among elected officials (Johnston and Romzek 1999), the potential cost savings accompanying privatization (real or perceived) may lead upper-level public managers to support privatization as a way to curry political favor. Cost savings may also incur financial rewards for public managers, as illustrated by county department heads who were awarded bonuses for outstanding management, in part based on the extent to which they had engaged in contracting out (Rusten 1999, 190). Ruhil et al. (1999) suggest that city managers gain reputational benefits from implementing successful government reforms, which in turn enables them to secure higher-paying positions in the national market.

For middle managers, privatization may alter daily tasks and thus the basis on which managerial performance is evaluated. Specifically, increased privatization calls for public managers to develop new skill sets, such as negotiating, monitoring, and managing contracts (Peters 1993; Kettl 1993; 2002). Consequently, it is reasonable to expect that managers will incur organizational rewards (e.g., higher pay and faster promotion) for competently executing these new duties (Savas 2000, 297). While empirical data on privatization's career benefits for middle managers are lacking, public choice theory provides a clear basis for expecting that agency managers evaluate privatization based on their expectations for its impacts on their self-interest. Accordingly it is expected that

Hypothesis 2: Agency managers who believe that managing contractors will lead to professional advancement will perceive privatization more positively than those who do not hold such perceptions.

In addition to supporting a public choice explanation of managerial perceptions of privatization (albeit one that alters traditional notions of the conditions leading to bureaucratic self-interest), a confirming result for the hypothesis may illuminate, in part, how adaptation to privatization occurs: by rewarding behavior that facilitates privatization. 
The extent of an agency manager's exposure to contractors may also influence perceptions of privatization via relational distance, defined as the degree to which people participate in one another's lives (Black 1976). A concept used by regulatory capture theorists, short relational distance is assumed to lead regulators to identify with regulated entities and lose their sense of organizational differentiation (Hood et al. 1999). Such familiarity compromises the independent judgment of regulators in regard to evaluating regulated communities, thereby biasing information about performance (Ashworth, Boyne, and Walker 2002).

Two dimensions of relational distance are frequency of contact and duration of relationships between parties. Scholars have detected the effects of frequent contact and long-term relationships on law enforcement behavior, including more favorable perceptions of the compliance motivations of regulated entities (Hood et al. 1999), a lower likelihood of pursuing punitive action by regulators (Grabosky and Braithwaite 1986), and higher incidences of police corruption (Simpson 1977). While these impacts are distinct from those that may arise from short relational distances between agency managers and contractors, they all share the common effect of triggering the regulator's positive identification with the regulated. This evidence leads to two hypotheses:

Hypothesis 3: Agency managers who are in more frequent contact with contractors outside the agency setting will perceive privatization more favorably than those who are in less frequent contact with contractors.

Hypothesis 4: Agency managers with more years of experience working with contractors will perceive privatization more favorably than those with less such experience.

A third dimension of relational distance is the degree of shared experiences that arise when regulators have worked previously in the industries of the regulated. When regulators share professional backgrounds with the regulated, they tend to perceive more positive compliance motives for regulated entities (Hood et al. 1999) and to be less rule-bound and prosecutorial in their interactions with the regulated (Hood et al. 1999; Grabosky and Braithwaite 1986). Extrapolating this link between regulators' experiences and perceptions of the regulated to agency managers and their contractors, it is expected that

Hypothesis 5: Agency managers with prior private-sector experience will perceive privatization more favorably than those with no such prior experience.

Perhaps the strongest indicator of relational distance, not directly tested in the literature, is the quality of relationships between regulators and the regulated. From this perspective, managers may build positive interpersonal relationships with contractors that cause them to perceive privatization in a more positive light. Thus the expectation is that

Hypothesis 6: Agency managers reporting positive relationships with contractors will perceive privatization more favorably than those reporting less positive contractor relationships.

The relational distance hypotheses (Hypotheses 3-6) assume that stronger relationships between managers and contractors (defined by quantity and quality of interactions) lead to more favorable managerial perceptions of privatization.

\section{Context for the Study}

This study, based on observations of the Georgia Department of Transportation (GDOT), began in 2001. The complete study is ongoing and designed to examine the agency's "consultant" management strategies. ${ }^{1}$ The project's data collection methods include case studies of GDOT projects, case studies of other state DOTs' consultant management practices, extensive semistructured interviews with man- 
agers from the agency and the contracting organizations, a review of the transportation literature, and a survey of midlevel managers. This section provides the context for the survey research gleaned through interviews, the case studies, and the literature review.

State transportation agencies historically have outsourced transportation system construction. However, over the last decade, state transportation agencies have come under increasing pressure to outsource other activities such as maintenance, information systems, entire road and port systems, and other administrative activities (Ellis, Guertin, and Shannon 2000; Witheford 1997; 1999). However, many state agencies have been reluctant to outsource engineering design work because it is a key point of quality control in the development of public infrastructure (Cochran et al. 2004). In any given transportation project, roughly 90 percent of the budget will go to construction and roughly 10 percent to engineering design (also called preconstruction).

Historically, design engineers have constituted the cultural heart of state DOTs. Entrylevel professional training is in civil engineering. Agency leaders typically work their way up by spending a portion of their career in the various engineering design departments. While the number of individuals involved in engineering design is relatively small (typically 10 percent or less of most state DOTs), over time they provide a talent pool of managerial leadership for the agency.

This study focuses on the contracting out of engineering design and inspection services that have traditionally been conducted in-house. One of the interesting aspects of GDOT's experience with privatization is that the decision to contract out did not come from a top-down political directive. While the State of Georgia has a history of several governors strongly promoting privatization as state policy, GDOT has remained largely immune from such pressure.

Several factors have created the conditions for privatization:
- Expansion of Public Transportation Programs-Under the last several governors, the state has sought to improve or increase highways and roads, resulting in a sharp increase in the number of projects being initiated under the State Transportation Implementation Plan.

- Public Finance Rules-The rules governing public bonds issued by the state to finance specific classes of transportation projects have changed and no longer permit the addition of state personnel, thereby limiting GDOT's ability to use state personnel on many projects.

- Downsizing of Workforce-The completion of the interstate highway system and changing public attitudes toward governmental functions and use of tax dollars have led GDOT, as well as other DOTs, to downsize their workforce. To illustrate, GDOT went from roughly 10,000 employees in the 1960s and early 1970 s to fewer than 6,000 employees in 2005. Attrition, reductions in force, and the elimination of vacant positions have become the norm rather than the exception among transportation agencies.

- Retirements-GDOT, like many agencies, is in the midst of a wave of retirements from the public service. These retirements are creating a personnel void that cannot be adequately filled due to restrictions created by public finance rules.

- Changing Civil Service Rules-Georgia recently eliminated the merit system governing civil service employees. Also eliminated were revolving-door rules preventing public officials from going to work for the private-sector firms with whom they interacted in their previous positions. The lifting of this constraint has led employees to retire from GDOT then go to work for higher-paying GDOT consultants.

Under these circumstances, many GDOT managers felt coerced to hire consultants. 
One of the findings from semistructured interviews with senior GDOT leadership is that the increased use of contractors is a second-best solution stemming from these constraints in their working environment. The initial attempt to cope with this situation was to create an Office of Consultant Design (OCD), which was supposed to be the unit that managed all projects hiring consultants. OCD was to act as a buffer and boundary-spanning unit shielding the other design engineers from the distraction of contract management. The quick expansion of the transportation program soon overwhelmed all efforts to buffer, however. The result has been large numbers of design engineers wearing two hats: one for producing the engineering design and the other for overseeing contractors performing the work.

This study focuses on the perceptions of GDOT managers regarding the impacts of consultant usage on the agency and themselves. To summarize, managers have developed these perceptions in the contexts of rapid expansion of the GDOT program, severe constraints on personnel availability, professional service contracts in which the focus is less on cost control and more on quality assurance, unsuccessful efforts to contain consultant management to a single unit (OCD), and expansion of the day-to-day tasks of engineering professionals to include both creating engineering designs (a desired activity because it utilizes their professional training) and managing the work of consultants (a less desired activity because it is perceived as bureaucratic and nonprofessional).

\section{Data}

Data were collected through a mail survey questionnaire of GDOT project managers. Survey content was based on input collected in 17 semistructured interviews with midlevel and senior agency managers between April 2002 and July 2003. Twelve case studies of consultant projects gathered between October 2002 and March 2003 informed parts of the survey not directly related to managerial perceptions of privatization. A draft survey was pretested in person with three key informants, two current employees, and one former employee. Feedback during these interviews served to refine question design and survey format: questions were added, concepts were clarified, and language was made consistent. The final survey comprised 16 pages, 33 questions, and nearly 300 individual items.

The sampling frame was developed by telephoning, e-mailing, and faxing all office heads within the agency to request contact information (including telephone numbers and mailing addresses) for employees working with consultants. Some offices reported no employees working with consultants, while one office provided contact information for 25 employees interacting with consultants. This effort yielded 286 employees from 8 divisions, 41 offices, and 7 districts. Employees ranged from project managers to administrative personnel to division heads.

The text of all survey materials stressed that participation was voluntary and that individual results and survey participation would be kept confidential. Survey materials also emphasized the agency's desire to better understand the issues and challenges of increased consultant usage from the perspective of its most affected personnel. To communicate the independent nature of the study, all survey materials were returned directly to the research team.

The survey process yielded 231 returned and completed questionnaires, representing an 81 percent response rate. The percentage of mail surveys received is proportional to the percentage distributed to agency offices, suggesting a sample highly representative of managers working with consultants across the organization. As for the substantive composition of managers in the sample, 65 percent had exclusively performed engineering-related tasks, including construction oversight, design engineering, and construction or preconstruction project management. Only 8 percent of managers in the sample had exclusively per- 
formed work in areas not represented by traditional engineering processes, such as legal counsel, auditing, planning, and accounting. Nineteen percent had performed both core and support roles, while 9 percent had performed tasks outside these categories.

\section{Measures}

This section describes the measures used in the two models of managerial perceptions of privatization. The dependent variable in the first model is the perceived impacts of privatization on the state transportation agency. The dependent variable in the second model is the perceived impacts of privatization on the respondent as an agency employee. The same explanatory variables are used in both models: three individual measures of professional identity, a scale measuring the perceived career benefits of privatization (or professional self-interest), and six individual measures of relational distance. Control variables include gender, education, agency tenure, and the percentage of a respondent's projects involving consultants.

A scale, adapted from Kakabadse and Kakabadse (2001), measures aggregate perceptions of privatization's effects on the agency. The scale sums a manager's assessments (ranging from 1 to 5 ) of 14 potential impacts of consultant usage on the agency. The impacts pertain to cost, effectiveness, administrative flexibility, reputation, agency capacity, employee motivation, accountability, and output quality. The lowest possible score is 14 , and the highest possible score is 70. Higher scores reflect more positive agency impacts (e.g., lower cost, improved agency reputation) and vice versa. Cronbach's alpha, which measures the reliability of a scale from 0 to 1 , is 0.92 for this scale.

A second scale, also adapted from Kakabadse and Kakabadse (2001), measures the perceived impacts of privatization on the responding manager. The scale is constructed by summing a manager's assessments (ranging from 1 to 5 ) of 7 impacts of privatization on employees, including workload, morale, motivation, productivity, job satisfaction, job security, and job success. Lower scores indicate negative impacts, and higher scores indicate positive impacts. The lowest possible score is 7 , and the highest possible score is 35 . Cronbach's alpha for this scale is 0.85 .

\section{Professional Identity}

Three measures operationalize professional identity. These measures are based on an agency manager's agreement or disagreement on a 1 to 5 Likert-type scale with the following statements: (1) My work should be primarily technical rather than managing consultants; (2) Professional reputation is more important to me than rank; and (3) I identify myself as a professional more so than a public servant. The first measure seeks to tap an agency manager's preference for technical tasks over contractor management, an orientation expected among professionals in highly privatized settings (Kettl 1993). In this study, such technical tasks are thought to pertain mostly to design engineering, which characterizes the lion's share of the study sample. The second measure pits professional reputation against rank, representing different sources of organizational prestige in professional and civil service personnel systems, respectively (Henry 2004). The third measure pits professional identity against public service identity, given the potential for professionals to espouse loyalty to their profession over loyalty to public service (Wilbern 1954).

\section{Beliefs about Privatization's Impacts on Professional Self-Interest}

Privatization's impact on professional selfinterest is measured using a scale that sums a survey respondent's level of agreement or disagreement (1 to 5 scale) with the following statements: (1) Employees who manage consultants are more quickly promoted than those who do not manage consultants; (2) Experience in managing consultants is necessary for advancement at this agency; (3) Consultant management experience is a good skill 
to have; and (4) Consultant management experience enhances my attractiveness to other employers. These statements were developed based on interviews with agency employees indicating their belief that consultant management experience provided opportunities for advancement within the agency, as well as skills marketable to the private sector. The Cronbach's alpha for the scale is 0.74 .

\section{Relationships between Public Managers and Contractors}

Relational distance, defined by Black (1976) as the degree to which people participate in one another's lives, is operationalized in six individual measures. A manager's experience with privatization is measured using three variables: the percentage of time currently devoted to managing consultants, the number of years devoted to working with consultants at the agency, and the number of years working with consultants elsewhere. The time length of relationships and experience is a common measure of relational distance, which has been correlated with more positive perceptions held by regulators of regulated entities (Hood et al. 1999; Grabosky and Braithwaite 1986; Simpson 1977).

A fourth measure of relational distance is the frequency of interactions between the manager and consultants taking place outside the agency setting. Survey respondents were asked to indicate the frequency (from 0 $=$ never to $4=$ frequently) with which they interacted with consultants in 10 settings: professional organization meetings, the agency's consultant relations advisory group, training sessions, alumni groups, service organizations, civic groups, sports clubs, youth groups, religious organizations, and social events. The higher the scale score, the more interaction takes place between the manager and consultants outside the agency. These items are based on ideas outlined in the social network literature (see Wasserman and Faust 1994). The Cronbach's alpha for the scale is 0.87 .

A fifth measure of relational distance is a respondent's private-sector experience, which is used to capture the shared-experience dimension of relational distance (Hood et al. 1999; Grabosky and Braithwaite 1986). Brudney, Hebert, and Wright (1999) also used privatesector experience (although not as a relational distance measure) to predict support for government reinvention reforms. Private-sector experience is measured using a dummy variable indicating whether (1) or not (0) the respondent has worked in the private sector on transportation-related issues.

The final measure of relational distance is a scale that gauges the quality of managercontractor relationships. The scale, adapted from Kakabadse and Kakabadse (2001), sums managers' assessments of relationships with contractors, ranging from 1 for the most negative version of the characteristic to 5 for the most positive version of the characteristic. Ten items are assessed: formality versus informality, flexibility versus inflexibility, distance versus friendship, closed versus open, disrespect versus respect, outsider versus partner, adversarial versus cooperative, declining versus improving, all business versus social, and distant versus involved. Thus total scores can range from 10 to 50 . Higher scores on the scale indicate more positive relationships. Cronbach's alpha for the scale is 0.90 .

\section{Control Variables}

Control variables include gender, level of education (0 = GED, 1 = high school diploma, 2 = some college education, 3 = associate's degree, 4 = undergraduate degree, 5 = graduate degree); length of time that the manager has worked at the agency (to control for those respondents who have witnessed increased privatization at the agency over time); and the percentage of a respondent's projects involving consultants (to account for the level of privatization experienced by the respondent).

\section{Results}

Because the study's dependent variables are ordinal-representing positive to negative impacts of privatization-the modeling process 
uses ordered probit regression. As opposed to linear regression modeling, which assumes a continuously distributed dependent variable, ordered probit modeling is appropriate for analyzing variables that have two or more categorical outcomes that can be ordered but for which the distances between categories is unknown (Long 1997, 114). Ordered probit is a nonlinear regression model that is an extension of logistic regression (Long 1997, 7). Two models are estimated: the perceived impacts of privatization on the agency and the perceived impacts of privatization on the respondent.

In the model of privatization's perceived agency impacts (Table 1), more positive consultant relationships and experience working with consultants outside the agency are both associated with favorable perceptions of privatization's impacts on the agency (both $p$ $<0.01$ ). These results are consistent with the hypotheses. However, higher percentages of respondent time devoted to consultant management correspond with more negative per- ceptions of privatization's agency impacts ( $p$ $<0.05)$, a result that contradicts expectations. Of the three professional identity measures, only a manager's preference for technical work over consultant management is associated with negative perceptions of privatization's agency impacts $(p<0.01)$. The length of a respondent's tenure at GDOT and the percentage of a respondent's projects involving consultants are significant positive influences on privatization perceptions ( $p<0.05$ and $p<$ 0.10 , respectively). McKelvey and Zavoina's $R^{2}$, which most closely approximates the ordinary least squares $R^{2}$ statistic for ordinal outcomes (Scott and Freese 2003, 163), is 0.39 for this model.

The second ordered probit model, of managerial perceptions of privatization's personal impacts, yields similar results to the first model, with a few exceptions (Table 2). As in the first model, positive contractor relationships and years working with contractors outside the agency are associated with more favorable perceptions of privatization's personal impacts

Table 1. Perceptions of Privatization's Agency Impacts

\begin{tabular}{lrrr}
\hline Characteristic/Measure & $\mathbf{b}$ & $\mathbf{z}^{\mathrm{a}}$ & $\boldsymbol{P}>|\mathbf{z}|$ \\
\hline Professional Identity & & & \\
$\quad$ Technical work/consultant management & -0.43 & -2.63 & 0.01 \\
$\quad$ Reputation/rank & -0.08 & -0.47 & 0.64 \\
$\quad$ Professional/public servant & 0.06 & 0.45 & 0.66 \\
\hline Professional Self-Interest & 0.06 & 1.53 & 0.13 \\
\hline Relational Distance & & & \\
$\quad$ Percentage of time devoted to contractor management & -0.01 & -2.33 & 0.02 \\
$\quad$ Years working with contractors within agency & 0.00 & -0.16 & 0.87 \\
$\quad$ Years working with contractors outside agency & 0.06 & 2.87 & 0.00 \\
$\quad$ Frequency of external interactions with contractors & 0.01 & 0.36 & 0.72 \\
$\quad$ Private-sector experience & -0.15 & -0.67 & 0.50 \\
$\quad$ Contractor relationships & 0.08 & 3.67 & 0.00 \\
\hline Control Variables & & & \\
$\quad$ Gender & 0.62 & 1.41 & 0.16 \\
$\quad$ Education & -0.08 & -0.77 & 0.44 \\
$\quad$ Years working for GDOT & 0.03 & 2.09 & 0.04 \\
$\quad$ Percentage of respondents' projects involving consultants & 0.10 & 1.77 & 0.08 \\
\hline McKelvey and Zavoina's $R^{2}=0.39$. $N=118$. & & & \\
a Based on White's heteroskedasticity robust standard errors. & & &
\end{tabular}


Table 2. Perceptions of Privatization's Personal Impacts

\begin{tabular}{lrrr}
\hline Characteristic/Measure & $\boldsymbol{b}$ & $\mathbf{z}^{\mathrm{a}}$ & $\mathbf{P}>|\mathbf{z}|$ \\
\hline Professional Identity & & & \\
$\quad$ Technical work/consultant management & -0.19 & -1.36 & 0.17 \\
$\quad$ Reputation/rank & 0.00 & -0.01 & 0.99 \\
$\quad$ Professional/public servant & 0.11 & 0.75 & 0.45 \\
\hline Professional Self-Interest & & & \\
\hline Relational Distance & & & \\
$\quad$ Percentage of time devoted to contractor management & -0.01 & -1.96 & 0.05 \\
$\quad$ Years working with contractors within agency & -0.05 & -1.69 & 0.09 \\
$\quad$ Years working with contractors outside agency & 0.05 & 2.61 & 0.01 \\
$\quad$ Frequency of external interactions with contractors & 0.02 & 1.66 & 0.10 \\
$\quad$ Private-sector experience & -0.14 & -0.70 & 0.48 \\
$\quad$ Contractor relationships & 0.08 & 4.66 & 0.00 \\
\hline Control Variables & & & \\
$\quad$ Gender & 0.30 & 0.90 & 0.37 \\
$\quad$ Education & 0.14 & 1.22 & 0.22 \\
$\quad$ Years working for GDOT & 0.02 & 1.44 & 0.15 \\
$\quad$ Percentage of respondents' projects involving consultants & 0.03 & 0.53 & 0.60 \\
\hline McKelvey and Zavoina's $R^{2}=0.34$. $N=118$. & & & \\
a Based on White's heteroskedasticity robust standard errors. & & &
\end{tabular}

( $p<0.01$ and $p<0.05$, respectively). Again, the percentage of time a respondent devotes to consultant management is associated with more negative privatization perceptions $(p$ $<0.05)$. However, two explanatory variables become marginally significant that were insignificant in the first model: the number of years working with consultants within the agency is associated with negative privatization perceptions, and the frequency of external interactions with consultants is associated with positive privatization perceptions (both $p$ $<0.10)$. The remaining explanatory variables are insignificant influences on perceptions of privatization's personal impacts. McKelvey and Zavoina's $R^{2}$ for this model is 0.34 .

\section{Discussion}

Privatization studies have not focused on the perceptions of affected managers-a significant knowledge gap given that reform efforts depend on managerial cooperation. This study takes a step toward filling that void by examining determinants of managerial perceptions of privatization within the Georgia Department of Transportation.

The expectation that managers with stronger professional identity would have more negative perceptions of privatization arose from the classic conceptualization of professionals as autonomous, operating within clear boundaries, and performing tasks for which they are trained (Mosher 1982). Negative reactions to privatization were expected based on the potential for contracting out to violate this autonomy, blur operational boundaries, and shift managers away from the work of their training and toward contract management. The data provide mixed support for this expectation. When measured as a preference for technical work over consultant management, professional identity is strongly correlated with negative perceptions of privatization's agency-but not personal-impacts. (These differential results may indicate a stronger concern for the agency's loss of technical capacity and a relative lack 
of concern that privatization will pose adverse career impacts.) Professional identity, when measured as a manager's perception as a professional versus a public servant, does not correlate with privatization perceptions. Professional identity also does not correlate with privatization perceptions when measured as the relative importance of professional reputation over rank. Considered together, these results suggest that privatization contradicts professional identity only to the extent that professional work tasks are altered. Alternatively, it is possible that a preference for technical work over consultant management is less indicative of professional identity and more indicative of managerial preferences regarding daily work tasks.

Public choice approaches that emphasize budget minimization led to the hypothesis that managers would perceive privatization positively to the extent that they believed privatization incurred professional benefits. The data indicate that managerial beliefs in privatization's career benefits do not significantly influence their perceptions of privatization. The results contradict public choice predictions that self-interest determines bureaucratic support for reform proposals (Wade 1979). As a consequence, there is little evidence that managerial support for privatization (in this setting, at least) can be bought with emoluments.

Based on regulatory capture theory (Hood et al. 1999; Ashworth, Boyne, and Walker 2002; Grabosky and Braithwaite 1986), stronger relationships between managers and consultants (defined both in terms of quality and quantity of relationships) were expected to yield more positive privatization perceptions. The results indicate that better relationships between managers and contractors lead to more favorable privatization perceptions; however, more time spent managing contractors is associated with negative perceptions of privatization's impacts. More experience with contractors outside GDOT correlates with more favorable privatization perceptions, while more experience with contractors within the agency only influences (in a negative direction) perceptions of privatization's personal impacts. More frequent external interactions with consultants correlate with more favorable perceptions of privatization's personal impacts but not its agency impacts. Finally, as Brudney, Hebert, and Wright (1999) found, a manager's experience in the private sector does not appear to influence privatization perceptions.

Several factors may account for these seemingly contradictory results. First, the percentage of time spent managing consultants may reflect the nature of managerial tasks more so than relational distances to contractors. If so, consultant management time may be similar to the preference for technical work over consultant management: both are associated with negative perceptions of privatization because they gauge a desire for different daily work activities. It is also possible that consultants who perform poorly require more managerial time, leading these time-burdened managers to have more negative perceptions of privatization's impacts.

Second, private-sector experience does not influence privatization perceptions, but external experience with consultants does (in a positive direction), suggesting that prior exposure to consultant practices in other settings-not exposure to market values-influences positive perceptions of privatization's impacts. But why does experience with GDOT consultants translate into negative perceptions of privatization's personal impacts? And why do agency tenure and a higher percentage of consultant projects (both control variables) correlate with positive perceptions of privatization's agency impacts? Perhaps these seeming contradictions signal an acknowledgement by more seasoned GDOT managers that, while consultants are valuable contributors to agency operations, the agency's increased use of consultants has undesirably altered their job content and career paths.

The context of this study is highly specific, featuring a state transportation agency dominated by civil engineers. However, the 
results may provide lessons to state and local agencies in which privatization's primary implementers are professionals who are asked to contract for professional services. Consider the areas of state government highlighted by the General Accounting Office for significant privatization activity $(1997,23)$. Of these areas, personnel with masters' and doctoral degrees are found among health, mental health, education, and social welfare agencies. There may be similar patterns of mixed perceptions among professionals in public service in regard to the influence of outsourcing on the performance of their organizations. In this way, the findings reflect those of other public professionals (Osborne 2000; Singer 2003).

\section{Conclusion}

The broader implications of this study depend on one's view of privatization. Those who believe that privatization threatens the integrity of public service (Frederickson 1997; Haque 2001) may happily conclude that managers appear not to base their perceptions of privatization on expected career benefits. Thus, managers' feelings about privatization (in this setting, at least) are not "bought" by career perquisites. On the other hand, those espousing this perspective may warn that public managers can be "captured" by contractors, much in the same way that regulators are captured by their regulated communities. If manager-contractor relationships color managerial views of privatization, then perhaps positive contractor relationships will also lead managers to increasingly contract out, even when doing so may not be cost effective or appropriate.

Those who believe that privatization paves the path to better government (Savas 2000) may view these study results as information for improving managerial acceptance of privatization. The implications of this study may be couched as advice to public executives, e.g., "build relationships between consultants and managers" and "be prepared for some managers to resist the shift from 'rowing' to 'steer- ing." From this perspective, one strategy for overcoming this resistance is to wait: as career civil servants retire, a new generation of public managers will be trained to know nothing of "rowing," only of "steering." Thus the resistance problem will resolve itself over time.

Regardless of whether one embraces its promises or sounds its warnings, privatization is a reality that affects public employees. Lower morale, reduced motivation, and impaired job satisfaction arising from the change in job responsibilities from agency production to consultant oversight are among the effects suggested by this study. At a minimum, managers should be aware of these human resource impacts and perhaps even seek to strike a balance in assigning employees consultant management and production responsibilities.

Much research is needed to continue this line of inquiry. Longitudinal data on privatization's impacts on managerial career trajectories is one such topic. The relationship between managerial perceptions of privatization and implementation effectiveness is another. Regardless of the approach, scholars should note privatization's impacts on the human fabric of public organizations-beyond cost savings and the mechanics of contractual arrangements - to achieve a fuller understanding of the consequences of the increasingly "hollow" state.

Leisha DeHart-Davis is an assistant professor in the Department of Public Administration at the University of Kansas. Her research interests include the effects of organization structure and government reform on public employees. Her research has been published in the Journal of Public Administration Research and Theory, Evaluation Review, and Policy Studies Journal.

Gordon Kingsley is an associate professor at the Georgia Institute of Technology. He teaches and conducts research in the fields of organization theory, public administration, and science and technology policy. His work has been published in 
Public Productivity and Management Review, Journal of Public Administration Research and Theory, and Public Administration Review.

\section{Note}

1. State departments of transportation use the term consultant to denote deliverers of professional services, including preconstruction engineering (Witheford 1999). The terms consultant and contractor are used interchangeably in this article.

\section{References}

Ashworth, R., G. A. Boyne, and R. M. Walker. 2002. Regulatory problems in the public sector: theories and cases. Policy and Politics 30:195-211.

Becker, Fred W., and A. J. Mackelprang. 1990. Attitudes of state legislators towards contracting for public services. American Review of Public Administration 30:175-89.

Berk, Richard A. 2003. Regression analysis: A constructive critique. Thousand Oaks, CA: Sage Publications.

Black, Donald. 1976. Behavior of law. New York: Academic Press.

Breton, Albert. 1974. The economic theory of representative government. Chicago: Aldine Publishing Company.

Breton, Albert, and Ronald Wintrobe. 1975. The equilibrium size of a budget-maximizing bureau: A note on Niskanen's theory of bureaucracy. Fournal of Political Economy 83:195-208.

Brudney, Jeffrey L., F. Ted Hebert, and Deil S. Wright. 1999. Reinventing government in the American states: Measuring and explaining administrative reform. Public Administration Review 59:19-30.

Buchanan, James M. 1977. Why does government grow? In Budgets and bureaucrats: The sources of government growth, ed. T. Borcherding. Durham, NC: Duke University Press.

Buchanan, James M., and Gordon Tullock. 1962. The calculus of consent: Logical foundations of constitutional democracy. Ann Arbor: University of Michigan Press.

Cochran, J. A., J. Croker, G. Kingsley, and P. Wolfe. 2004. Best practices in consultant management at state departments of transportation. Transportation Research Record 1885:42-47.

Cooper, Phillip J. 2003. Governing by contract: Challenges and opportunities for public managers. In Public affairs and policy administration, ed. D. Kettl. Washington, DC: CQ Press.

Dunleavy, Patrick. 1992. Democracy, bureaucracy and public choice: Economic explanations in political science. New York: Prentice Hall.

Durant, Robert F., and Jerome S. Legge Jr. 2002. Politics, public opinion, and privatization in France: Assessing the calculus of consent for market reforms. Public Administration Review 62:307-23.
Edwards, J. Terry, John Nalbandian, and Kenneth R. Wedel. 1981. Individuals' values and professional education: Implications for practice and education. Administration and Society 13:123-43.

Ellis, R. D., B. D. Guertin, and S. Shannon. 2000. Best management practices for the out-sourcing of design and construction engineering services on FDOT construction projects. Gainesville: University of Florida, Department of Civil Engineering.

Frederickson, H. G. 1997. The spirit of public administration. San Francisco: Jossey-Bass.

GAO. See U.S. General Accounting Office.

Goode, William J. 1969. The theoretical limits of professionalization. In The semi-professions and their organization, ed. A. Etzione. Toronto: Free Press.

Grabosky, Peter, and John Braithwaite. 1986. Of manners gentle: Enforcement strategies of Australian business regulatory agencies. Melbourne: Oxford University Press.

Greene, Charles N. 1978. Identification modes of professionals: Relationship with formalization, role strain, and alienation. Academy of Management fournal 21:486-92.

Hall, Richard C. 1968. Professionalization and bureaucratization. American Sociological Review 33:92-104.

Haque, M. S. 1996. Public service under challenge in the age of privatization. Governance 9:186-216.

-2001. The diminishing publicness of public service under the current mode of governance. Public Administration Review 61:65-82.

Henry, Nicholas. 2004. Public administration and public affairs. 9th ed. Upper Saddle River, NJ: Prentice Hall.

Hood, Christopher, Colin Scott, Oliver James, George Jones, and Tony Travers. 1999. Regulation inside government. New York: Oxford University Press.

Johnston, J. M., and B. S. Romzek. 1999. Contracting and accountability in state Medicaid reform: Rhetoric, theories, and reality. Public Administration Review 59:383-99.

Kakabadse, A., and N. Kakabadse. 2001. Outsourcing in the public sector: A comparative analysis of practice, capability, and impact. Public Administration and Development 21:401-13.

Kearney, Richard C., and Carmine P. F. Scavo. 2001. Reinventing government in reformed municipalities: Manager, mayor and council actions. Urban Affairs Review 37:43-66.

Kearney, Richard C., Barry M. Feldman, and Carmine P. F. Scavo. 2000. Reinventing government: City manager attitudes and actions. Public Administration Review 60:535-48.

Kettl, Donald F. 1993. Sharing power: Public governance and private markets. Washington, DC: Brookings Institution.

2002. The transformation of governance: Public administration for twenty-first century America. Baltimore, MD: Johns Hopkins University Press.

Lipsky, Michael. 1980. Street level bureaucracy: Dilemmas of the individual in public service. New York: Russell Sage Foundation. 
Long, J. Scott. 1997. Models for categorical and dependent variables, advanced quantitative techniques in the social sciences. Thousand Oaks, CA: Sage.

Long, J. Scott, and Jeremy Freese. 2003. Regression models for categorical dependent variables using Stata. College Station, TX: Stata Press.

Maynard-Moody, Steven, and Michael Musheno. 2003. Cops, teachers, counselors: Stories from the front lines of public service. Ann Arbor: University of Michigan Press.

Miller, George A. 1967. Professionals in bureaucracy: Alienation among industrial scientists and engineers. American Sociological Review 32:755-68.

Moon, M. J., and P. deLeon. 2001. Municipal reinvention: Managerial values and diffusion among municipalities. Fournal of Public Administration Research and Theory 11:327-51.

Mosher, Frederick C. 1982. Democracy and the public service. 2nd ed. New York: Oxford University Press.

National Public Radio. 2005. Private contractors in Iraq. www.npr.org/templates/story/story.php?storyId $=4712776$.

Niskanen, William A. 1971. Bureaucracy and representative government. Chicago: Aldine-Atherton.

Osborne, S. P. 2000. Public-private partnerships: Theory and practice in international perspective. London: Routledge.

Peters, B. G. 1993. Searching for a role-the civil-service in American democracy. International Political Science Review 14:373-86.

President's Commission on Privatization. 1988. Privatization: Towards more effective government. Washington, DC: President's Commission on Privatization.

Rainey, H. G. 2003. Understanding and managing public organizations. 3rd ed. San Francisco: Jossey-Bass.

Ruhil, Anirudh V. S., M. Schneider, P. Teske, and J. Byung-Moon. 1999. Institutions and reform: Reinventing local government. Urban Affairs Review 34:433-55.

Rusten, Allen C. 1999. Implementing privatization in the public sector. In Contracting out government services, ed. P. Seidenstat. Westport, CT: Praeger.

Savas, Emanuel E. 2000. Privatization and public-private partnerships. New York: Chatham House.
Schott, Richard L. 1976. Public administration as a profession: Problems and prospects. Public Administration Review 36:253-59.

Seidenstat, Paul. 1999. The mechanics of contracting out. In Contracting out government services, ed. P. Seidenstat. Westport, CT: Praeger.

Sigelman, Lee. 1986. The bureaucrat as budget maximizer: An assumption examined. Public Budgeting and Finance (Spring): 50-59.

Simpson, Antony E. 1977. The literature on police corruption. New York: John Jay Press.

Singer, Peter. 2003. Corporate warriors: The rise of the privatized military industry. Ithaca, NY: Cornell University Press.

Thompson, L., and R. C. Elling. 2000. Mapping patterns of support for privatization in the mass public: The case of Michigan. Public Administration Review 60:338-48.

U.S. General Accounting Office (GAO). 1997. Privatization: Lessons learned by state and local governments. In Report to the Chairman, House Republican Task Force on Privatization, GAO/GGD-97-48. Washington, DC: GAO.

Wade, L. L. 1979. Public administration, public choice and the pathos of reform. Review of Politics 41:34474.

Wasserman, Stanley, and Katherine Faust. 1994. Social network analysis: Methods and applications. New York: Cambridge University Press.

Willbern, York. 1954. Professionalism in the public service: Too little or too much? Public Administration Review 14:13-21.

Wise, L. R., and S. Szucs. 1996. The public private cleavage in a welfare state: Attitudes toward public management reform. Governance 9:43-70.

Witheford, D. K. 1997. NCHRP synthesis of Highway Practice 246: Outsourcing of state highway facilities and services. Washington, DC: Transportation Research Board, National Research Council.

1999. NCHRP synthesis of highway practice 277: Consultants for DOT preconstruction engineering work. Washington, DC: Transportation Research Board, National Research Council. 